\title{
RELEVANCE OF SOCIAL MEDIA IN CORPORATE WORLD
}

\author{
Marko Pavićevićc ${ }^{*}$, \\ Avetik Pashayan², \\ Mohammad Razaul Karim ${ }^{3}$ \\ ${ }^{1}$ Singidunum University, \\ Belgrade, Serbia \\ ${ }^{2}$ National University of Architecture \\ and Construction of Armenia, \\ Yerevan, Armenia \\ ${ }^{3}$ Comilla University, \\ Cumilla, Bangladesh
}

\begin{abstract}
:
Social media is becoming increasingly relevant for corporate businesses. It is becoming increasingly relevant part of everyday life for overall population. It creates virtual communities that are very important for corporations in order to adjust to market tendencies. Great advantage of social media for corporations is being able to promote their business in a more efficient way, creating virtual communities that can help establish close connection with clients and to create a narrative that can bring benefit. Opportunity for companies via social media is creating long lasting bond with customers that can constantly be improved and moderated for the sake of everyone's interest. Furthermore, social media, today, is an important factor in recruiting new employees. Interactive way of communicating is another milestone where companies can attract clients, maintain good relations, and create promotions that are much more creative in nature.
\end{abstract}

Keywords:

social media, communication, marketing, virtual communities, business strategy.

\section{INTRODUCTION}

Digital era is the new reality for which we are never really sure where it will lead us. Certainly, one legitimate argument is that corporate functioning will be impossible without the Internet and social media. One of the great advantages of digital era is that communication will be much easier between corporations and clients. Management of vast information will be the challenge. Furthermore, it is very difficult to imagine that an individual does not have at least one profile on social media. This means it is crucial for corporations to be present online in order to connect with its customers and potential clients.

Social media is a term for web pages and applications whose aim is to create communication and interaction between people. "Social media employ mobile and web-based technologies to create highly interactive platforms via which individuals and communities share, co-create, discuss, and modify user-generated content" (Kietzmann, Hermkens, McCarthy \& Silvestere 2011, p. 241). Creation of virtual community is the goal of social media. This virtual community is an opportunity for companies to attract customers and to promote its products and services. One of the aims of social media, also, is transparency where companies can be fully transparent in their intentions, problems, ideas, visions and etc. Furthermore, participation is another advantage where companies can allow customers to be a part of corporate vision through their personal input.

Global connections and being part of virtual reality is tendency that corporation can use in order to take a full advantage that social media provides. For companies, social media is relevant because it is becoming incorporated in all parts of public

Correspondence:

Marko Pavićević

marko.pavicevic@singidunum.ac.rs life (Dijck \& Poell, 2013). 
This research paper will analyze importance of social media in corporate world. Firstly, it will analyze advantages that social media provides for corporations. Secondly, it will analyze opportunities that social media brings to corporation. Thirdly, it will explain the role of social media in everyday corporate life. Fourthly, paper will analyze connection between social media and corporate communication. Finally, there will be analysis of the relevance of social media for corporate marketing.

\section{ADVATAGES OF SOCIAL MEDIA FOR CORPORATIONS}

There are three reasons for corporations choosing to use social media for corporate business: overall promotion of their business, forming a narrative or in other words, creating virtual community and to the extend, bigger audience and reaching more potential customers (Carim \& Warwick, 2013). Brand awareness is one the most important factors for the success of the company. New customers and young generations claim that they learn about new companies through the Internet and social media. This trend is an absolute necessity for companies to follow and to make sure they persist with it. Furthermore, in the world where companies, usually, have negative image of being completely profit oriented, social media have the role of creating trust within customers, which leads to brand humanization through promotion of social values that are important to them. For example, the company can promote itself as the defender of global warming. In that way, it can attract customers with the same ideals and tendencies. Also, constant interaction with clients is practically impossible without social media. Social media transcends borders, language barriers, time barriers and allows companies and customers to have connection at any given time of the day. Official sites are, still, most import factor for company in terms of information gathering. Nevertheless, social media sites increase clients and potential client's presence at the official company's site. Goal is to attract clients and link social media information to the official site of the company. Free promotion is, probably, the greatest advantage of social media that can serve as a promotion partner in connecting company with potential clients. This can lead to an increase in sales because every new contact at social media can be a potential buyer that brings benefit to the company.

Social media contributes to 'two-way street' communication in corporate world, which can be extended between different parties. Furthermore, we cannot control communication at social media because there are different inputs by many users. Also, social media creates tendency for coordinated tendencies, but it lacks coordination of those tendencies (Lee, Oh \& Kim, 2013).
This two-way street communication provides a negative and positive view of a company. Clients can express their opinion and company will get the input that can be used in order to improve its practices and to satisfy customer needs and tendencies. Downside is that tendencies at social media are not controllable, but on the other hand, they provide the company with ability to react in time of crisis. For example, social media can help the company to connect fast with clients and to publicly apologize for malpractice. Also, it is true that social media creates desire to form a coordinated strategy, but because of its nature, it is difficult to have one. Nevertheless, there can be a part of coordinated strategy, aimed at satisfying customer needs, such as customer support where clients can always get relevant information from companies.

Competition has been, and always will be, obsession for companies. Every company wants to have information about other companies' tendencies, goals, visions, in other words, secrets that can be used with the aim of improving its own position. Since social media bring transparency, it is easier for companies to gather information about each other. Also, it is easier to get information about what customers think about competition. All this, gives possibility for companies to adapt, change and to improve its practices for the sake of attracting more customers. We live in a very dynamic world where it is very easy to miss information that can be relevant for success of a company. Corporations, in increasingly digital world, cannot afford to miss information that can be crucial for the success of a business. Lastly, huge advantage of social media for companies is targeted promotion. Companies can promote their business with the help of target groups that are based on geographic and demographic bases. For example, it can make a different add for clients that are above sixty years old and add for clients that are younger, which is based on generational tendencies.

\section{OPPORTUNITIES SOCIAL MEDIA PROVIDES FOR CORPORATIONS}

Social media, above all, gives opportunity to corporations to create long lasting relationships with the general public. This visibility helps corporations increase their presence in the media, create trust and improve positive perception of their products and services. Social media helps corporations analyze how much general public talks about them and what is the perception of them. Greater presence at social media brings greater attention, which means there is greater brand recognition and loyalty (Yang \& Kent, 2014). Brand psychology argue that the brand value is in the perception of another person. We need to understand human mind in order to create valuable brand. 
Social media help companies gather information about those perceptions, which help them take directions, necessary to improve their brand value.

Social media allows companies to use pictures in order to create better relationship with customers and to promote its products and services in a more vivid way. Visual approach to promotion and communication creates better understanding of corporate culture and vision, which creates better experience for customers. Picture is worth thousand words, which means there is visual approach that enhances and improves interactions with customers. Furthermore, people, by their nature, love interaction and to be able to answer questions. Social media provides opportunity for customers and potential customers to directly ask a company about issues that relate to them. When we are able to ask question, we feel respected and valued. Companies can show their appreciation by being constantly available to customers at social media. Surveys are another example of relevant way of finding out what customers think, want and like. They stimulate interests, provide information and require questions that result in important information for companies and their businesses.

Traditional research is very important for companies to improve their business practices and enhance overall efficiency of their business strategy. Accordingly, digital research is becoming more relevant in corporate world, where companies can create interesting research patterns in order to attract clients as another way of getting to know them. Social media brings openness, which means it makes an opportunity for creating emotions that are subtle way to attract customer. For example, company can make fun of its own products and service, which will attract customers and their curiosity. Furthermore, people like facts and statistics, which means they want tangible data on the matter that is in their interest. Every sharing of facts makes people more informed and more interested in a particular company. For example, Starbuck can share online their new strategy of recycling that will make our planet cleaner. Customers who are environmentalist can identify with that strategy. In other words, "by making social media and intricate part of the marketing and sales strategy, companies could develop deeper relationship with customers, increase collaboration via two-way conversation, gain incredible customer insight, and as a result, achieve true 360-degree view of their customer, all while continuity to profit" (Rodriguez, Peterson \& Krishanan 2012, p. 376).

\section{ROLE OF SOCIAL MEDIA FOR CORPORATIONS}

For corporations, hiring process and attracting appropriate candidates for the job is imperative for future success. Human resource managers rely on social media to attract and find potential candidates for the job. It gives opportunity to companies to do research on potential candidates for the job. For example, company can see communication skills of potential candidate, necessary for the specific job. Furthermore, company is able to pay attention, through social media, whether an employee is behaving according to company norms and values. For example, if company has very strict feminist values, it can check if their employees respect women and does not insult them on social media. Simultaneously, it can validate whether employee is telling the trught. Employee can argue that his absence is because of the illness and company can validate that claim online, through social media, whether he is really sick, or he went for vacation abroad. Above all, social media is very important tool for companies to plan and promote events. There is a saying "if it did not happen on Facebook, it did not happen at all in reality ". Social media and virtual world became relevant to the companies and their business practices as much as the real world. Universities can use social media for promotion and for targeting particular groups that are relevant. Firstly, universities can use social media to share important news that are relevant for students. Secondly, universities can use social media to stimulate debate between the students and that information can be used latter to improve its practices (Belanger, Bali \& Longden, 2013). Situation with SARS-CoV-2 virus showed us how relevant social media is for the functioning of universities. Most effective way for students to get information and to talk between themselves how university will continue with its practices was through social media.

Public relation is crucial factor for companies to maintain good relationship with clients and partners. For example, LinkedIn is a professional platform that allows companies to maintain good professional relationship with clients and partners. For example, university can organize academic conferences and invite all participants through social media. Simultaneously, it can redirect online users by creating links between companies' web sites and personal accounts. All of the above, would be impossible without local research. Social media provides companies with tools to analyze market tendencies and to adjust accordingly. If the overall public tendency is more toward eco-friendly environment, companies can adjust their products and services and the potential clients can identify with the company. It is all about anticipation and making sure to create prospect for the business. 
Social media provides better communication with clients, which can help company forecast the business tendencies in the market. Company needs to carefully plan its strategy at social media. Proper employees, mostly millennials, work in this area of business. Traditional marketing and the use of social media need to be synchronized for the sake of successful business practices (Sodeman \& Gibson, 2015). Modern technology is always rejected at first because of contemporary tendencies of doing business. Companies will be more successful if they embrace new technologies being offered to them, while maintaining their values and goals.

\section{SOCIAL MEDIA AND CORPORATE COMMUNICATION}

Regarding communication, social media has helped companies build interactive approach with their customers and partners, rather than just sharing important information. This means that both sides can express their desires, frustrations, and tendencies, which is a huge opportunity for companies to adjust to market tendencies (Cho, Furey \& Mohr, 2016). In other words, power of social media is the listening that gives opportunity to corporations to analyze people's tendencies in a different communities and groups. This will provide knowledge of trends, problems and challenges that can help companies identify potential clients. All this knowledge gives opportunity for companies to create particular content for particular group. For example, if there is a feminist movement among young generation, company can create programs for young female leaders to follow that trend. It is an imperative for the whole corporate team to synchronize its communication system with social media, which will enable them to be available at any time for any issue necessary. A company, firstly, needs to educate the public, through social media, with its values and visions before the promotion of its products and services. Furthermore, visual appearance is another milestone in social media where companies can share, not just pictures, but videos that provide more vivid experience for customers. People are visualists and it is more likely that they will remember the company if they live through experience. For example, Starbuck celebrated the month of "Pride" in the United States by giving support to LGBT population. Company shared many pictures, videos and made research that stimulated debate and presence online. In this way, company communicated with their customers and created a bond that will reaffirm brand's value. Final aim of communication through social media is creating emotion in people that affects and attracts clients.
Research argues that companies, rarely, have a strategic approach at social media, rather they improvise and experiment on ad hoc basis. Furthermore, there is no clear goal, which is integrated with corporate vision. Above all, problem is that, usually, corporate communication is not integrated with social media communication (Macnamara \& Zerfass, 2012). Firstly, it is necessary for the company to make constant experiments with social media. For example, company Netflix in time of pandemic, organized conferences where people can connect with experts and ask about their problems and about virus in general. Secondly, company needs to constantly distribute its promotional material online. Clients need to be constantly informed about companies' new products, services and tendencies. For example, Lego company shares its new prototypes on YouTube for clients to see and to get feedback from them. Thirdly, companies need to share same content on different social media. There is a need for different approach at different social media platforms and that is why companies need to synchronize their vision and business practices in order to be able to share it. Fourthly, consistency of the message is imperative for companies to create one unified vision and share it online. If one company fights against discrimination among people, it needs to promote itself in this way on every social media platform and to provide an example in reality.

\section{RELEVANCE OF SOCIAL MEDIA FOR CORPORATE MARKETING}

For social media corporate marketing to be successful, company needs web site that is effective, integrated and to express corporate vision, orientation, goal and etc. Furthermore, marketing team need to be very knowledgeable and able to synchronize traditional market and digital marketing. Synchronization between traditional and digital market is important because it gives full experience to customers, who can use social media to follow company claims, trends and services. Digital marketing through social media is not independent strategy, rather a toll that accompanies overall corporate marketing strategy (Constantinides, 2014). Nevertheless, there are many important reasons, why company should use social media in order to improve its marketing strategy. Above all, social media can help companies improve their brand image, which is essential for the success of the company. Company Domino allow their clients to create their own pizza flavor online. In this way, they create an image of the company that is open minded and ready to adjust to clients' needs and tendencies. Additionally, social media can reduce costs when it comes to marketing. Many online platforms allow for free promotion, which in turn, can allow companies to diversify and to reduce cost of traditional marketing. 
For example, direct relation with the clients, reduces costs for traditional way of communicating and promoting. Companies do not need to pay phone bills or to print promotional materials when they can do that online through social media platforms.

Being informed and having knowledge is imperative for companies to be successful and to adjust their strategies. Being present on Internet with the help of social media, companies can gather knowledge of different trends, tendencies and etc. This gives them power to adjust their business practices and to provide products and services that will make potential clients interested. Likewise, this provides companies with bigger range in the market. With the help of social media, companies can transcend geographic and demographic barriers and act accordingly. Furthermore, social media allows companies to follow their peers and their tendencies and business practices, which can help them with their strategy. Overall, there is a great power in being informed through social media that help companies promote their vision and constantly adapt. Aim of viral marketing is creating online communities of similar interests that will remain loyal to the brand. Companies do not just promote their products online, they bring people together who strive for similar products to discuss and share experience. It is difficult to measure success of marketing through social media. Companies need to focus on qualitative, rather than quantitative approach to measuring effectiveness of viral marketing (Miller \& Lammas, 2010). Aim is to think outside of box and traditional way of doing marketing. Companies need to develop online communities, to bring people together and to be creative in order for them to materialize from social media and viral marketing.

\section{CONCLUSION}

In the present and near future, it would be impossible for companies to do business and to be successful if they are not present on different social media platforms. In the long term, our whole lives will be digitalized and accordingly, companies need to adjust their visions, goals, and business practices. Social media provides opportunity for companies to achieve interactive communication and ability to respond in efficient way so that customers are satisfied. Furthermore, it gives the ability to keep an eye on competition, more importantly, to gather knowledge of what clients think of competition. Role that social media has, such as paying close attention to employees and establishing appropriate public relation is imperative for the success of the companies and staying updated with relevant information. Above all, social media gives power to customers to express their desires, wishes and frustrations, which is, in fact, a huge benefit for companies to be able to adjust accordingly to those tendencies. Lastly, social media contributed to viral marketing, in other words, it can make traditional marketing more successful.

\section{LITERATURE}

Bélanger, H., Bali, S., \& Longden, B. (2013). How Canadian Universities Use Social Media to Brand Themselves. Tertiary Education and Management 20(1), 14-29.

Carim, L., \& Warwick, C. (2013). Use of Social Media for Corporate Communications by Research-Funding Organisations in the UK. Public Relations Review 39(5), 521-125.

Cho, M., Furey, L., \& Mohr, T. (2016). Communicating Corporate Social Responsibility on Social Media. Business and Professional Communication Quarterly 80(1), 52-69.

Constantinides, E. (2014). Foundations of Social Media Marketing. Procedia - Social and Behavioral Sciences 148, 40-57.

Dijck, V. J., \& Poell, T. (2013). Understanding Social Media Logic. Media and Communication 1(1), 2-14.

Kietzmann, J., Hermkens, K., Mccarthy, P. I., \& Silvestre, B. (2011). Social Media? Get Serious! Understanding the Functional Building Blocks of Social Media. Business Horizons 54(3), 241-51.

Lee, K., Oh, W., \& Kim, N. (2013). Social Media for Socially Responsible Firms: Analysis of Fortune 500's Twitter Profiles and Their CSR/CSIR Ratings. Journal of Business Ethics 118(4), 791-806.

Macnamara, J., \& Zerfass, A. (2012). Social Media Communication in Organizations: The Challenges of Balancing Openness, Strategy, and Management. International Journal of Strategic Communication 6(4), 287-308.

Miller, R., \& Lammas, N. (2010). Social media and its implications for viral marketing. Asia Pacific Public Relations Journal 11, 1-9.

Rodriguez, M., Peterson, M. R., \& Krishnan, V. (2012). Social Media's Influence on Business-to-Business Sales Performance. Journal of Personal Selling \& Sales Management 32(3), 365-78.

Sodeman, A. W., \& Gibson, A. L. (2015). Corporate Usage of Social Media and Social Networking Services in the USA. Communications in Computer and Information Science Multidisciplinary Social Networks Research, 264-278.

Yang, A., \& Kent, M. (2014) Social Media and Organizational Visibility: A Sample of Fortune 500 Corporations. Public Relations Review 40(3), 562-64. 